\title{
Hołosko - znany ośrodek leczenia gruźlicy na kresach południowo-wschodnich Drugiej Rzeczypospolitej Polskiej
}

\section{Hołosko - a well-known centre for the treatment of tuberculosis in the south-eastern borderland of the Second Republic of Poland}

\author{
Andrzej Kierzek ${ }^{\circledR}$, Małgorzata Paprocka-Borowicz², Jadwiga Kuciel-Lewandowska², Krzysztof Tuszyński³, \\ Jacek Kotuła ${ }^{4}$
}

${ }^{1}$ Karkonoska Państwowa Szkoła Wyższa, Zakład Fizjoterapii, ul. Lwówecka 18, 58-503 Jelenia Góra

${ }^{2}$ Uniwersytet Medyczny im. Piastów Śląskich we Wrocławiu, Katedra Fizjoterapii, ul. Grunwaldzka 2, 50-355 Wrocław

${ }^{3}$ Wyższa Szkoła Logistyki w Poznaniu, Zakład Profilaktyki Lekarskiej, ul. Ewarysta Estkowskiego 6, 61-755 Poznań

${ }^{4}$ Specjalistyczny Gabinet Stomatologiczny, ul. Wyszyńskiego 1, 65-525 Zielona Góra

$\triangle$ andrzejkierzek@wp.pl

\section{ABSTRACT}

The geographic and climatic conditions of Hołosko Wielkie, a locality near Lviv, are presented at the beginning. The medical and organizational activities of the tuberculosis sanatorium opened in this place in 1909 and expanded in 1911 are analyzed. The development of tuberculosis therapy, especially of its early form, are analyzed with full particulars. The doctors working in the spa and the results of treatment in this medical institution are fully presented.

Keywords: history of pulmonology; history of otorhinolaryngology; history of the south-eastern borderland of the Second Republic of Poland.

\section{ABSTRAKT}

W artykule przedstawiono warunki geograficzne i klimatyczne Hołoska Wielkiego - miejscowości koło Lwowa oraz działalność medyczną i organizacyjną sanatorium przeciwgruźliczego otwartego w 1909 r. i rozbudowanego w 1911 r. Szczegółowo omówiono rozwój terapii gruźlicy, szczególnie postaci wczesnych. Zaprezentowano lekarzy pracujących w uzdrowisku oraz rezultaty terapii w tej placówce medycznej.

Słowa kluczowe: historia pulmonologii; historia otorynolaryngologii; historia Kresów Południowo-Wschodnich II Rzeczypospolitej Polskiej.
Z gruźlicą walczono od niepamiętnych czasów. Nie potrafiono jednak jej pokonać aż do 1943 r., kiedy to wynaleziono streptomycynę , a w latach późniejszych inne swoiście działające leki.

Z gruźlicą walkę prowadzono także na ziemiach polskich, również w warunkach sanatoryjnych. W 1857 r. przez Józefa Dietla (1804-1878), lekarza, rektora Uniwersytetu Jagiellońskiego, polityka, została powołana do życia Komisja Balneologiczna przy Krakowskim Towarzystwie Naukowym skupiająca wybitnych przedstawicieli świata nauki. W połowie lat 80. XIX w. Bolesław Lutostański (1837-1890), lekarz zdrojowy, po dokonaniu wnikliwej analizy działalności uzdrowisk położonych na ziemiach polskich, w pracy pt. „Przemysł zdrojowo-leczniczy i ustawa dla zdrojowisk krajowych. Fakta i uwagi" pisał o niedocenianiu polskich uzdrowisk, ich tworzyw naturalnych oraz klimatu w zwalczaniu gruźlicy [1]. Gdy w 1877 r. Komisja Balneologiczna uległa rozwiązaniu, powołano stałą Komisję ds. Balneologii, Klimatologii i Hydrologii Krajowej. Z zakresu profilaktyki gruźlicy cenne było także powstanie w 1884 r. Towarzystwa Kolonii Letnich w Warszawie założonego przez Stanisława Markiewicza (1839-1911), lekarza higienistę i społecznika. Rocznie wysyłano na wieś ponad 3000 dzieci, przeważnie z gruźliczych rodzin. W Galicji kolonie w Rabce organizował w 1887 r. prof. Maciej Leon
Jakubowski (1837-1915), lekarz i rektor Uniwersytetu Jagiellońskiego, a w rok później park gier i zabaw na krakowskich Błoniach - Henryk Jordan (1842-1907), lekarz i profesor Uniwersytetu Jagiellońskiego. Ta ostatnia akcja zapoczątkowała powstawanie tzw. ogródków jordanowskich, następnie m.in. w Nowym Sączu, Stryju i Kołomyi [2]. Na przełomie XIX i XX w. dołączył do nich Henryk Dobrzycki (1841-1914), lekarz, muzykolog, kompozytor, filantrop, jeden z pionierów lecznictwa sanatoryjnego, założyciel pierwszego na ziemiach polskich i chyba drugiego na świecie (pierwsze sanatorium ludowe zorganizował Peter Detweiller w Falkenstein w 1876 r.) podmiejskiego sanatorium ludowego w Mieni pod Warszawą, gdzie leczeni byli „chorzy w dziewięćdziesięciu procentach pochodz(ący) z klasy całkowicie niezamożnej, można powiedzieć biednej”. Dobrzycki twierdził, że gruźlicę można leczyć nie tylko w klimacie wysokogórskim, ale także nizinnym [3, 4]. Był to początek tworzenia kolonii leśnych, szczególnie dla ubogich rekonwalescentów opuszczających szpitale. Dały one początek wielu innym, podobnym w takim działaniu placówkom, m.in. Rudce k. Warszawy dla niezamożnej uczącej się młodzieży, w Otwocku, Chojnach k. Łodzi, Zakopanem, Worochcie, Tatarowie nad Prutem [5, 6]. Historyczną chwilą walki z gruźlicą na ziemiach polskich była inicjatywa Tomasza Wiktora 
Janiszewskiego (1867-1939), higienisty, polityka, ówczesnego lekarza gminy Zakopane, a późniejszego m.in. w odrodzonej Rzeczypospolitej Ministra Zdrowia Publicznego, profesora Uniwersytetu Warszawskiego, który w 1900 r. na IX Zjeździe Lekarzy i Przyrodników Polskich w Krakowie zaproponował utworzenie Sekcji Gruźliczej. Wniosek ten doczekał się urzeczywistnienia w tym samym roku w postaci Towarzystwa Budowy Sanatorjów Ludowych dla dotkniętych Gruźlicą [7].

W 1905 r. w Krakowie powstało Polskie Towarzystwo Balneologiczne. Słowo „polskie” podkreślało, że obejmuje swym zasięgiem wszystkie ziemie polskie pod zaborami [4, 8]. Ono także czynnie włączyło się do walki z gruźlicą.

Gdy pozytywne dokonania sanatoryjne Hermana Brehmera (1826-1889) dowiodły, że może dojść do znacznej poprawy, a nieraz w początkowych stadiach do wyleczenia gruźlicy tą drogą, wówczas na przełomie XIX i XX w. zaczęto intensywniej starać się ją zwalczać.

W stadiach początkowych tej choroby szczególnie pomocne było leczenie w warunkach sanatoryjnych za pomocą bardzo prostych środków: odpowiedniej klimatoterapii na terenie dobrze położonym, zazwyczaj nieco górzystym, otoczonym sosnowymi lasami; stosownej diety; umiarkowanych zabiegów wodnych. Taka kuracja musiała być przeprowadzana pod lekarskim nadzorem. Metoda ta nazwana była przez Alfreda Marcina Sokołowskiego (1849-1924), pioniera polskiej pulmonologii i laryngologii, climatotherapia nostras. Stosowana była bowiem na naszych ziemiach za pomocą „naszych domowych i powszednich środków". Nieco lepsze wyniki otrzymywane w Goerbersdorfie czy Davos, zdaniem Sokołowskiego, były rezultatem czystego par excellence powietrza. Sokołowski podzielał zdanie Hermana Webera, który twierdził, że przez „odpowiednie zużytkowanie danych warunków ziemi ojczystej w wielu przypadkach możemy osiągnąć też same korzystne wyniki, co i przez pobyt w oddalonych miejscowościach kuracyjnych" [9]. Gerszon Gabriel Lewin von Hersz (1867-1939), lekarz i historyk medycyny, słusznie zauważył, że do sanatoriów wysokogórskich przybywali pacjenci przeważnie zamożni, pozostający tamże usque ad effectum, przeciętnie ponad $220 \mathrm{dni}$ w roku, podczas gdy do sanatoriów ludowych przede wszystkim robotnicy, osoby mniej zamożne i zupełnie ubogie, szukające „ostatniej deski ratunku”, przebywając w nich średnio tylko ok. 90 dni [10].

Jednym z pierwszych etapów walki z gruźlicą było zakładanie uzdrowisk ludowych tworzonych na wzór prywatnych sanatoriów dla chorych zamożniejszych. Powstawało wiele tego typu placówek, zwłaszcza w Niemczech oraz krajach skandynawskich. Zrozumiano, że walkę z tą groźną chorobą należało toczyć wielopłaszczyznowo, z uwzględnieniem szeroko pojętej profilaktyki. Tworzono dyspensatoria, zaczęto budować domy dla chorych nieuleczalnych, zakładano uzdrowiska leśne, kolonie leśne etc. Szczególną rolę odgrywały grupy dyspanseryjne, bowiem to na te placówki spadła rola prawdziwej walki z gruźlicą jako chorobą epidemiczną. Zadaniem tych grup było niszczenie ognisk epidemicznych przez rozumne uświadamianie chorych, pomoc materialną, pomoc lekarską oraz przez umieszczanie niebezpiecznych dla otoczenia chorych w odpowiednich zakładach. Obok opieki dla chorych dorosłych prowadzono także, nawet bardziej intensywnie, opiekę nad dziećmi zagrożonymi lub chorymi na gruźlicę. W tej walce przodowała Francja [11].

Działacze Lwowskiego Towarzystwa Walki z Gruźlicą (LTWG), które istniało w latach 1902-1939 i w 1926 r. liczyło 10, a w 1937 - 200 członków; w latach 1934-1939 wydawało „Ruch Przeciwgruźliczy” [12], w pierwszej dekadzie XX w. zamierzali w pobliżu Lwowa założyć takie sanatorium. Wybór padł na Hołosko Wielkie, wieś położoną na wysokiej, ok. 15 m skarpie, stoku wzgórz Roztocza Lwowsko-Tomaszowskiego na wysokości 360 m n.p.m., posiadających dwa tarasy, w odległości ok. 900 m od drogi z Lwowa do Brzuchowic. Miejscowość sąsiadowała na południe z Kleparowem, na wschód z Zamarstynowem, na północ z Brzuchowicami i na zachód z Rzęsną Polską. Południowo-wschodnią część obszaru zajmowała podmokła dolina Pełtwi, reszta była pagórkowata [13, 14, 15]. Od zimnych wiatrów od północy chroniły wzgórza, a otwarta na południe przestrzeń skąpana była zwykle w słońcu. Wiatry, szczególnie południowo-wschodnie, nie dokuczały samemu uzdrowisku [16].

Pracę autorzy oparli na publikacjach Marcina Selzera zamieszczanych we „Lwowskim Tygodniku Lekarskim”. Działalność tej leczniczej placówki po 1913 r. została zanaalizowana w oparciu o pracę Lesława Węgrzynowskiego i Felicji Hałacińskiej. Autorom nie udało się dotrzeć do innych źródeł. Przed napisaniem publikacji autorzy zastanawiali się, czy warto będzie podjąć taki temat. Wątpliwości ich rozwiała konstatacja Lelewela: „Pisać, co można, a nie frasować się, że tu i ówdzie czegoś brak. Przyjdzie drugi i trzeci - i dopełnią. Tak się tworzyły i dziś jeszcze tworzą wszystkie historje".

Hołosko, urokliwie położoną miejscowość, założył w $1402 \mathrm{r}$. Piotr Zimmerman, a akt nadania potwierdzony został przez Władysława Jagiełłę w 1424 r. W 1470 r. Rada Lwowska nadała mieszczaninowi Janowi Hanelowi ,to uroczysko dla osadzenia go rolnikom, i za opłatą pewnego czynszu do kassy miejskiej”. Później miejscowość dziedziczyli Szymonowicze, rodzina słynnego Szymona Symonidesa. W początkach XVII w., w latach 1610 i 1615 kolegium ławników lwowskich kupiło część wsi, zakładając „swoje dworki”; podatki z nich płacono także do miejskiej kasy [17]. W miejscowości z cenniejszych zabytków znajdowała się m.in. cerkiew pw. Zaśnięcia św. Anny, wzniesiona w 1775 r.

Działacze LTWG w 1908 r. założyli dyspensatorium, a w 1909 r. wystąpili z zamiarem stworzenia ludowego uzdrowiska leśnego. Pomogły władze Lwowa, przydzielając odpowiednie miejsce. Na rzecz sanatorium część swoich gruntów zrzekła się poważana lwowska kupiecka rodzina Riedlów. Pomogła szybka i hojna ofiarność innych prywatnych ludzi, pomogło Towarzystwo Czerwonego Krzyża, użyczając dwa baraki doeckerowskie najnowszej konstrukcji wraz z całym urządzeniem szpitalnym dla 26 chorych [11, 18, 19, 20, 21, 22, 23].

Uzdrowisko zostało otwarte 11 lipca 1909 r. i było niezbyt szczęśliwie usytuowane przy drodze, ze względu na turkot nielicznych wprawdzie pojazdów i kurz, nie było to jednak zbyt dokuczliwe dzięki znacznej gęstości lasu między barakami uzdrowiska a gościńcem i nieco wyższe jego położenie. 
Budynek administracyjny mieścił m.in. kuchnię, śpichlerz, pokój dla służby i pomieszczenie administratora. W celu przechowywania żywności wykopano piwnicę i lodownię. Około $30 \mathrm{~m}$ od budynku administracyjnego mieściły się baraki wyglądające jak szpitalne sale. Każdy barak mieścił 13 łóżek oraz leżaki do werandowania. W środku stał stół, wokół którego w dni słotne siadano do obiadów i kolacji. W czasie dni pogodnych jadano na świeżym powietrzu. Okna baraków były dniem i nocą otwarte. W każdym z baraków znajdował się wychodek, z którego nieczystości kilka razy dziennie opróżniano do odpowiednich dołów [11]. Utworzenie takiej jednostki opieki zdrowotnej uważano za eksperyment mający służyć przyszłym tego typu medycznym placówkom.

Początkowo planowano założyć jedynie dzienne schronisko leśne, z którego chorzy mieliby wracać na noc do domów. Odstąpiono jednak od tego zamiaru po uwzględnieniu trudności związanych z transportem chorych [11]. W zakładzie prowadzono akcję profilaktyczną, w którą, niejednokrotnie z materialnym wsparciem, szczególnie zaangażował się miejscowy lekarz [18].

Postanowiono przedłużyć działanie sanatorium na miesiące zimowe. Baraki typu dockerowskiego nie mogły być jednak używane zimą. 0 nich to dziennikarz „Nowin Lekarskich” pisał, że „prezentują się przyjemnie i elegancko”. Posiadały jednak wady, które precyzował następująco: „ciepłota bardzo niejednostajna, kontrolowanie i pielęgnowanie chorych trudniejsze, potrzeba więcej posługi, niebezpieczeństwo ognia, trudne utrzymanie czystości (...)” [24].

Działacze LTWG postanowili przystąpić do budowy pawilonu stałego. W lipcu 1911 r. wybudowano wg własnych planów pierwszy w Galicji pawilon dla celów sanatoryjnych systemu Frommera, który oddano do użytkowania 1 października tego roku. Pawilon ten składał się z dwóch korytarzy, z których frontowy, długości ponad $26 \mathrm{~m}$, tworzył obszerną, bardzo jasną i słoneczną, zimą oszkloną, werandę. Z korytarza tylnego wchodziło się do pokoi dla chorych, do klozetów i łazienki. Oba korytarze regulowały ciepłotę w salach chorych, mimo że ściany wykonane były z odpowiednio izolowanych desek. Pawilon mieścił 4 pokoje dla 14-18 chorych, ambulatorium oraz kuchnię wraz z pokoikiem do wydawania potraw. Woda sprowadzana była rurociągiem ze studni oddalonej o $40 \mathrm{~m}$ od pawilonu. Automatyczne piece zapewniały temperaturę do $16^{\circ} \mathrm{C}$, nawet przy większych mrozach. Ustalono 3-miesięczne sezony; m.in. jesienny od października do końca grudnia oraz zimowy - do końca marca [19]. W 1912 r. informowano, że sanatorium składało się z jednego pawilonu zimowego na 18 łóżek i dwóch baraków letnich na 26 łóżek oraz że w owym roku miał powstać drugi pawilon zimowy [25].

Wybuch I wojny światowej zastał hołoskie sanatorium w pełnym rozwoju. W czasie zajęcia tych ziem przez wojska rosyjskie praca nie ustawała. Budowano nowy pawilon, zakładano wodociągi. Po odbiciu Lwowa przez armię austro-węgierską w Hołosku powstał rezerwowy szpital wojskowy, którym zarządzał dr Selzer. Władze wojskowe zainstalowały elektryczne oświetlenie. Walki polsko-ukraińskie niszczyły Hołosko, także jego sanatoryjne budynki. W końcu 1920 r. w LTWG lekarską działalność rozpoczęli Antoni Sabatowski (1880-1967), późniejszy profesor balneologii, oraz Lesław Węgrzynowski (1885-1956), farmakolog i ftyzjatra.

W 1921 r. budynki sanatorium zajęło Wojsko Polskie, by w roku następnym oddać je z powrotem LTWG. Działalność przychodni sanatoryjnej zredukowana była do minimum, a lecznictwem sanatoryjnym ciągle zarządzał dr Selzer. Sanatorium zostało odnowione, a wyposażenie uzupełnione.

W 1926 r. reprezentant LTWG został zaproszony na posiedzenia Lwowskiej Miejskiej Rady Zdrowia. We wrześniu tego roku zorganizowano we Lwowie pierwszą wystawę przeciwgruźliczą, zapoczątkowano Lotne Kolumny Przeciwgruźlicze uświadamiające społeczeństwo w małych miastach i wsiach o problemie gruźlicy i sposobach jej zwalczania. Te fakty w istotny sposób wpłynęły na rozwój lecznictwa sanatoryjnego także w Hołosku, gdzie przez odpowiednie adaptacje przygotowano jeden z pawilonów do działalności w porze zimowej.

W początkach $1927 \mathrm{r}$. istniały 42 miejsca całoroczne, a w lecie powiększono liczbę chorych o dalsze 22 osoby. Zmieniono także nazwę sanatorium na Lecznicę w Hołosku Lwowskiego Towarzystwa Walki z Gruźlicą. Ta medyczna placówka została szpitalem sanatoryjnym. Nic więc dziwnego, że dyrekcja zmuszona została do dalszych licznych inwestycji, jak wybudowanie kancelarii administracyjnej, odnowienie kuchni oraz spiżarni. Przede wszystkim jednak lecznicę skanalizowano, założono centralne ogrzewanie, oświetlenie elektryczne etc.

Rok 1928 zapisał się w historii Hołoska jako okres wyczerpujących wysiłków w celu powiększenia terenu o 13 morgów gruntu oraz wybudowania kolejnego pawilonu, do czego w znaczny sposób przyczyniły się działania Magistratu m. Lwowa. Lwowskie władze doprowadziły także do powstania Poradni i Przychodni Przeciwgruźliczej w Zamarstynowie i w 1929 r. w Zimnej Wodzie, odciążając nieco hołoską lecznicę.

Nowy pawilon w Hołosku został oddany do użytku w 1930 r., co doprowadziło do znacznego zwiększenia liczby łóżek w okresie letnim do 150, a zimowym do 94 osób. W ciągu tego roku spośród studentek medycyny Uniwersytetu Jana Kazimierza i nauczycielek zorganizowano w Hołosku Komitet Pomocy mający za zadanie objęcie opieką przede wszystkim chorych z rodzin ubogich, dostarczając im także żywności i odzienia.

Taka intensywna działalność władz samorządowych Lwowa doprowadziła do tego, że w 1931 r. „Lwów (stał się) pierwszym miastem w Polsce, w którym zawiązał się związek celowy wszystkich czynników społecznych i oficjalnych przeznaczonych do walki z gruźlicą (...) na zasadzie terytorjalnej pod kierownictwem Magistratu".

W ciągu 1931 r. Powiatowy Wydział Samorządowy we Lwowie rozpoczął oraz dokończył budowę drogi dojazdowej do Hołoska [7]. W początkach trzeciej dekady XX w. chorzy werandowali w porze letniej na leśnej polanie należącej do zakładu lub na specjalnie urządzonej werandzie otwartej, tzw. słonecznej [23, 26].

Od 1934 r. zakład nosił nazwę Lecznica Lwowskiego Towarzystwa Walki z Gruźlicą, a chorzy mieli do dyspozycji kilka pawilonów (ryc. 1). Pierwszy pawilon im. dra Tomasza Janiszewskiego, drewniany, omurowany, posiadał 24 łóżka. Następny, 


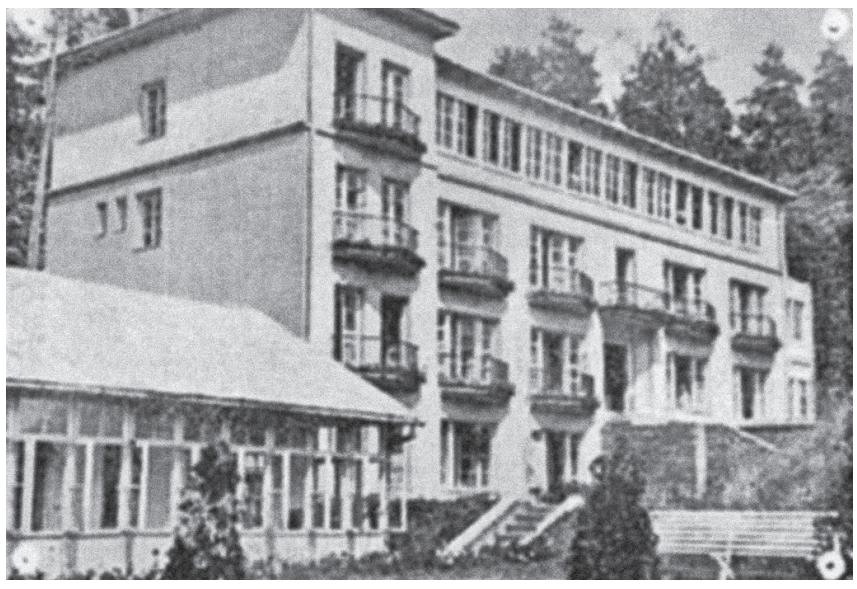

RYCINA 1. Lecznica Lwowskiego Towarzystwa Walki z Gruźlicą w Hołosku koło Lwowa [16]

2-piętrowy, także omurowany, ogrzewany centralnie, z olbrzymimi oknami zajmującymi prawie całą frontową ścianę, wyposażony we wszystkie nowoczesne urządzenia sanitarne z bieżącą, także ciepłą wodą, mieścił 45 łóżek oraz salę operacyjną. Oddział wewnętrzny mieścił 26-łóżkowy pawilon im. prof. Józefa Wiczkowskiego, który także był ogrzewany centralnie i miał bieżącą wodę. Ostatni, usytuowany na górnym tarasie pawilon letni, miał 36 łóżek. Posiadał także leżalnię, która była wykorzystywana, gdy było ciepło. Zakład w lecie mógł pomieścić 152 , a zimą 96 chorych. W budynku administracji mieściły się: pokój do badań, laboratorium, kancelarie, biblioteka, kuchnie, spiżarnie, jadalnie dla lekarzy. W owym 1934 r. w zakładzie istniały dwa oddziały. Do oddziału chorób wewnętrznych przyjmowano chorych internistycznych, z wyjątkiem chorób zakaźnych, szczególnie z nieżytami oskrzeli, astmą oskrzelową, ropniami płuc, stanami rekonwalescencji wymagającymi leczenia przede wszystkim dietetycznego. Ci chorzy nie mieli kontaktu z gruźlicą. Do oddziału gruźliczego kwalifikowano chorych z wszystkimi postaciami gruźlicy. Nie przyjmowano chorych w stadiach terminalnych. Z rozrywek oferowano bogato wyposażoną bibliotekę, sale rozrywkowe, radio, ale bogactwo sanatorium stanowił przede wszystkim urokliwy park [16].

\section{PACJENCI, LEKARZE}

Przyjmowano chorych w początkowych stadiach gruźlicy oraz osoby zagrożone tą chorobą, u których istniała uzasadniona nadzieja, że po 3 miesiącach będzie możliwy powrót do pracy ze znaczną poprawą, bez gorączki i ewentualnych powikłań. Znaczną część chorych stanowili robotnicy z Kas Chorych lub fabryki tytoniu w Winnikach ze stwierdzonymi zmianami gruźliczymi w płucach bądź osoby przyjmowane w celach profilaktycznych, ze znacznym osłabieniem, ciągle się męczące [21]. Nie mogli znaleźć tu miejsca, z przyczyn oczywistych, chorzy wysoko gorączkujący oraz chorzy z gruźlicą otwartą. Klasyfikacja pacjentów była bardzo rygorystyczna. Czuwali nad nią: prof. Józef Wiczkowski, prymariusz oddziału chorób wewnętrznych Szpitala Powszechnego we Lwowie
Bett, W. Ziembicki i Marcin Selzer. Wiczkowski, autor m.in. książki pt. „Lwów, jego rozwój i stan kulturalny oraz przewodnik po mieście" (Lwów 1907), uczynił Hołosko pozauniwersytecką placówką dydaktyczną dla studentów medycyny Uniwersytetu Jana Kazimierza, których uczono o istocie i leczeniu gruźlicy [22]. W latach 1923-1925 w Hołosku ordynował dr Stanisław Angielski (1894-1935), a od października 1926 r. asystentem został dr Herman Zdzisław Scheuring (1894-1963), późniejszy dyrektor sanatorium w Worochcie [7].

W 1934 r. personel lekarski składał się z dyrektora i prymariusza oraz dwóch starszych asystentów. Konsultantami byli: ginekolog, chirurg oraz laryngolog. Laryngologiem w latach 1934-1940 był lekarz Kliniki Otolaryngologicznej Uniwersytetu Jana Kazimierza, dr med. Tadeusz Ceypek [27]. Chorzy mieli komfortową możliwość uzyskania fachowej specjalistycznej pomocy z lwowskiego uniwersytetu. Do dyspozycji był także dobrze wykwalifikowany personel pielęgniarski [16].

Ważnym zadaniem lekarzy było dążenie do „zmiany postaci gruźlicy otwartej w gruźlicę zamkniętą", czyli uczynienie chorych nieprątkującymi [20].

\section{DIAGNOSTYKA GRUŹLICY}

Selzer informował, że gruźlicę rozpoznawano metodami osłuchowymi, opukowymi, badaniem plwociny na obecność prątków oraz metodami biologicznymi; stosowano odczyn Pirqueta i odczyn tuberkulinowy; czasem korzystano z badań radiologicznych [19]. Dziwi zatem konstatacja Kazimierza Tyszki z 1932 r., że zakład „nie posiada (...) aparatu rentgenowskiego nawet dyagnostycznego i posiadać go prędko nie będzie nawet w przyszłości, gdyż przewody Wielkiej Elektrowni Okręgowej biegną daleko od lecznicy i nie będą mogły dostarczać prądu do sanatorjum, małe zaś jego rozmiary nie pozwalają na wystawienie elektrowni własnej z akumulatorami" [28]. Możliwe, że badania radiologiczne wykonywano poza sanatorium.

\section{SPOSOBY LECZENIA}

Pewna część chorych już po kilku dniach opuszczała zakład. Byli to ludzie niepotrafiący się poddać sanatoryjnemu rygorowi albo nierozumiejący istoty choroby $i$ „leczenia bez lekarstwa”. Niejednokrotnie chorzy, gdy zaczęli się już czuć nieco lepiej, zaczynali myśleć o powrocie do domów, skąd rodziny „prześladowały” ich listami o swojej nędzy, starając się w ten sposób o szybszy powrót do domu [21].

Leczenie farmakologiczne lub chirurgiczne gruźlicy nabierało właściwego sensu, jeżeli choćby przez pewien czas było wspomagane leczeniem opartym na zasadach sanatoryjnych. Stała kontrola skuteczności przyjmowanych leków, właściwie pojęta rekonwalescencja po przebytych zabiegach chirurgicznych, wyłączenie czynników zewnętrznych oraz dyscyplina życia zespołowego ludzi dotkniętych tą samą choroba stanowiły wówczas główny cel „swoistości” (w ówczesnym pojęciu) takiego leczenia. 
Według Selzera postępowanie terapeutyczne oparte było na zasadach przyjętych przez Hermanna Brehmera i Petera Dettweilera, a więc na używaniu świeżego czystego powietrza, na dobrym odżywianiu chorych oraz na ich „spokoju moralnym i fizycznym". Chorzy używali świeżego powietrza larga manu. Przyczyniał się do tego odpowiedni klimat, jak również piaszczysty grunt, który nie doprowadzał do powstawania błota. Wiosną obowiązywała pacjentów praca w ogródku i polu, zimą - saneczkowanie na specjalnym torze usytuowanym obok uzdrowiska. Ograniczanie ruchu było konieczne u chorych ze zwyżką ciepłoty ogólnej ustroju o kilka dziesiętnych stopnia [20]. Chorzy zmuszeni byli dostosować się do regulaminu, a wszelkie jego znaczniejsze przekroczenia kończyły się wykluczeniem z zakładu.

W ówczesnym pojęciu „leczenie specyficzne” polegało przede wszystkim na wstrzykiwaniu środków zawierających arszenik, leczeniu klimatycznym i dietetycznym.

W Hołosku próbowano także leczenia gruźlicy tuberkuliną. Warto przypomnieć w skrócie historię leczenia tym środkiem. Robert Koch, jak i wielu innych poważnych naukowców owego okresu, poszukiwał usilnie leku przeciwgruźliczego. W 1890 r. uzyskał tuberkulinę, która stanowiła zagęszczony przesącz prątków hodowanych na bulionie z gliceryną. Sądził, że wyciąg z zabitych prątków będzie w stanie uleczyć gruźlicę. Tuberkulina budziła nadzieję. Znaczną część lekarskiego świata ogarnął wtedy „szał tuberkulinowy”. W roku następnym dla Kocha stworzono instytut chorób zakaźnych w Berlinie z oddziałem klinicznym i laboratoriami. Rudolf Virchow, niezwykle sceptycznie nastawiony do tego odkrycia, opublikował wyniki badań chorych leczonych autopsyjne tym środkiem, które nie były pomyślne dla Kocha. Doprowadziły jednak Kocha do zmiany stanowiska nt. tuberkuliny jako środka leczniczego. Nieprzydatność tuberkuliny jako środka leczniczego przewidział jako jeden z pierwszych Odon Bujwid (1857-1942), polski bakteriolog i higienista [30]. Obserwowano jednak, że tuberkulina miała pewne znaczenie diagnostyczne [30, 31].

W Hołosku selekcjonowano szczególne przypadki chorych, u których w plwocinie znajdowano prątki. Tuberkulinę stosowano przez 6 miesięcy. Selzer stosował sposób Sahliego, aplikując tuberkulinę w nader małych dawkach przez dłuższy czas; używał starej tuberkuliny Kocha (Alttuberkulin). Różnicę między starą tuberkuliną (Alttuberkulin) a nową tuberkuliną (Neutuberculin) Tadeusz Koźniewski upatrywał następująco: nowa tuberkulina ,jest to przetwór z hodowli bakterii gruźliczych, a więc zawiera tożsamo czynne ciało (toksynę), ale nadto ciała prątków, które usuwano z pierwotnej starej tuberkuliny". Dla ścisłości historycznej podać trzeba, że nową tuberkulinę Koch wprowadził 7 lat po starej [32, 33]. Zdaniem M. Godlewskiego nowa tuberkulina miała tę wyższość nad starą (Kocha, Beranecka, Denysa), że „nawet u wysoko gorączkujących chorych ze skutkiem stosowana być mo(gła)” [34, 35, 36].

Zaczynano od dawek najniższych, tzn. o 1 milionowej części jednego grama starej tuberkuliny. Selzer twierdził, że „nigdy żadnej szkody ostrożnemi wstrzykiwaniami nie wyrzadza(ło) się choremu”. Poprawa była widoczna, „a badanie końcowe było niespodzianką dla tych, którzy widzieli tych chorych przy opuszczeniu zakładu". Opierając się na wieloletniej obserwacji, Selzer twierdził, że podobnie jak w sanatoryjnych zakładach w Alland i Hörgas, stara tuberkulina była najodpowiedniejsza dla tego typu leczenia $[18,20]$. W latach 1920-1921 aplikowano podskórnie mleko gotowane 2-krotnie przed wstrzyknięciem, w 3-dniowych odstępach, wilości od 0,5 $\mathrm{cm}^{3}$; najwyższa dawka wynosiła $4 \mathrm{~cm}^{3}$, co było leczeniem typowo bodźcowym [37]. W 1934 r. stosowano m.in. odmę sztuczną, ekstirpację nerwu przeponowego, plomby parafinowe, torakoplastyki [16].

\section{WYNIKI LECZENIA}

Wyniki leczenia zamieszczał Marcin Selzer w specjalnych sprawozdaniach na łamach „Lwowskiego Tygodnika Lekarskiego". W 1909 r., w pierwszym roku istnienia tej placówki, leczono 26 chorych, wśród których bywali uczniowie różnego typu szkół, urzędnicy, robotnicy obojga płci. Pacjenci chętnie poddawali się przepisom regulaminu i byli wdzięczni za umożliwienie im tego typu leczenia. U tych pacjentów uzyskano poprawę podmiotową sprawy chorobowej, „uspokojenie się" objawów osłuchowych, znaczne zmniejszenie się kaszlu, znaczny przyrost na wadze (nawet do $1 \mathrm{~kg}$ po tygodniowym leczeniu). Selzer był jednak świadomy, że nie było to wyleczenie, „że groźba gruźlicy nad nimi wisząca, (nie) znikła”. Był przekonany, że chorzy „(n)auczeni w uzdrowisku, jak żyć i zachowywać się, będą [...] niewątpliwie pionierami rozszerzającymi zasady walki z gruźlicą w swojem otoczeniu". Owi pacjenci nie zniknęli z pola widzenia hołoskich lekarzy; byli badani co dwa miesiące w następnym roku po opuszczeniu zakładu [11].

W sprawozdaniu z $1911 \mathrm{r}$. Selzer donosił, że przyjmowano także chorych ambulatoryjnych, leczonych identycznie jak zakładowych; w nocy umieszczano ich jednak w najbliższych chłopskich domach, które często wcześniej pod względem higienicznym wizy tował zakładowy lekarz. W owym $1911 \mathrm{r}$. leczono 26 chorych zakładowych obojga płci (uczniów, studentów, nauczycieli, urzędników, robotników) oraz 3 ambulatoryjnych; z tego przyjęto 11 chorych z zajęciem jednego szczytu płuca, 5 pacjentów miało zmiany w szczycie oraz powikłania, jak zrosty opłucnowe po wysiękach, zapalenie węzłów chłonnych etc. [18]. W okresie od 1 października 1911 r. do końca marca 1912 r. leczono 33 osoby, z czego 24 było chorych na gruźlicę, $13 \mathrm{w}$ pierwszym stadium, a $11 \mathrm{w}$ przejściu do drugiego. $\mathrm{Z}$ tych 24 pacjentów: 19 opuściło zakład ze znaczną poprawą, zdolnych do pracy, 3 - z poprawą, ale jeszcze niezdolnych do pracy, 2 - bez zmiany w stanie zdrowia. U 5 chorych prątkujących po leczeniu, uzyskano „zamknięcie ogniska” [20].

W ciągu 1912 r. zakład opuściło 106 osób. Ciekawy jest przekrój socjologiczny chorych. To m.in. 22 robotników tytoniowych, 7 krawców, 6 kowali, po 4 gimnazyalistów i ślusarzy, po 3 pisarzy adwokackich i urzędników prywatnych, po 2 dyetetariuszy, elektrotechników, murarzy, palaczy maszynowych, pomocników szybowych, praktykantów leśnictwa, służących, stolarzy, tokarzy i zecerów, a także: chłopka, cieśla, fryzyer, kupiec, kuśnierz, magister farmacyi, mechanik, metalowiec, modniarka, nauczyciel ludowy, rusznikarz, subjekt, 
szwaczka, telefonista kolejowy, wiertacz i woźny [21]. Dużą poprawę stwierdzono u 48, poprawę - u 34, stan niezmieniony - u 23, a pogorszenie u 1 chorego. Niezdolnych do pracy okazało się 9 chorych, co stanowiło 8,5\%. Był to ważna informacja dla instytucji kierujących chorych do zakładu, które po stosunkowo krótkim czasie odzyskały robotników zdolnych do pracy [22].

W latach 1920-1921 Selzer leczył 218 chorych w turnusach liczących przeciętnie 60 dni (najdłużej 5 miesięcy). Wyniki leczenia, w którym włączono leczenie bodźcowe w postaci podskórnego stosowania mleka, o czym wspomniano wcześniej, były podobne do poprzednich [37].

W 1924 r., kiedy to m.in. oddano jeden pawilon na kolonię wakacyjną, leczeniem objęto 132 chorych w wieku 16-62 lat, z tego 127 pacjentów z gruźlicą „zamkniętą”, 12 z rozpadową gruźlicą jednego płuca leczonych sztuczną odmą piersiową, 2 z gruźlicą kości i 1 chorą z gruźlicą otrzewnej. Przeciętny czas leczenia wynosił 3 miesiące. Chorych leczono werandowaniem, krótkotrwałymi ćwiczeniami gimnastycznymi i spacerami leśnymi. Wykonywano m.in. odmy piersiowe, nakłucia i aspiracje wysięków i ropni. U 67 chorych wstrzykiwano dożylnie 10-25\% roztworu chlorku wapnia, uzyskując pewne obniżenie się ciepłoty, zwolnienie tętna. U 22 chorych stosowano antytuberkulinę, w 103 przypadkach tebecinę Dostala, uzyskując zwiększenie limfocy tozy i leukocy tozy, zwiększenie łaknienia, polepszenie samopoczucia [26].

\section{ZAKOŃCZENIE}

Marcin Selzer na podstawie obserwacji chorych w prowadzonym przez siebie zakładzie oraz w innych tego typu europejskich placówkach doszedł do wniosku, że leczenie chorych w tych strefach klimatycznych, wśród których mieszkali i pracowali, nie ustępowało w niczym leczeniu w innym klimacie (nadmorskim, górskim), a poprawa stanu chorobowego bywała trwalsza niż u chorych wracających „z klimatów odmiennych”. Była to cenna wiadomość dla Kasy Chorych oraz dyrekcji zakładów pracy Lwowa kierujących swoich pacjentów do Hołoska, którego znaczenie istotnie wzrastało. Świadczy o tym fakt, że jeden ze zjazdów rządowych na początku II dekady XX w. miał w swoim programie zwiedzanie tego ciekawego uzdrowiska [22].

\section{PIŚMIENNICTWO}

1. Lutostański B. Przemysł zdrojowo-leczniczy i ustawa dla zdrojowisk krajowych. Kraków: Fakta i uwagi; 1886. p. 7.

2. Moskwa Z. Z dziejów gruźlicy w XIX na ziemiach polskich. Wiad Lek 1985;38(16):1189.

3. Dobrzycki H. Sanatoryum dla chorych piersiowych w Mieni. Medycyna 1899;18(3):44.

4. Migała M. Rozwój terapii balneoklimatycznej na Górnym Śląsku w aspekcie leczenia gruźlicy (druga połowa XIX i pierwsza polowa XX wieku). Opole: 2009. p. 124-43.

5. Sokołowski A. Wykłady kliniczne chorób dróg oddechowych. Nauka o suchotach płucnych. Wykłady wygłoszone na Uniwersytecie Warszawskim. Warszawa: 1920/1921. p. 239-40.
6. Saysse-Tobiczyk K. Uzdrowiska polskie. Ilustrowany przewodnik po zdrojowiskach, stacjach klimatycznych, kąpieliskach morskich, wczasowiskach i miejscowościach wypoczynkowych. Warszawa: 1947. p. 27.

7. Węgrzynowski L, Hałacińska F. Rys historii. Twa walki z Gruźlicą we Lwowie. Walka Gruźl Chor Płuc 1986;22(5):18-22.

8. Gantkowski P. Działalność Polskiego Towarzystwa Balneologicznego. Pamiętnik Polskiego Towarzystwa Balneologicznego 1930;9:25.

9. Sokołowski A. W sprawie leczenia klimatem swojskim (Climatotherapia nostras). Gaz Lek 1882;17(8):188.

10. Lewin G. Walka z gruźlicą za pomocą sanatoryów ludowych swojskich. Krytyka Lekarska 1903;7(6):124.

11. Selzer M. Wyniki leczenia w uzdrowisku ludowym w Hołosku. Lw Tyg Lek 1909;4(49):565-8.

12. Brożek K. Polskie stowarzyszenia lekarskie 1805-1951. Warszawa: 2005. p. 101.

13. Sulimirski F, Chlebowski B, Walewski W, editors. Słownik geograficzny Królestwa Polskiego i innych krajów słowiańskich. T. III. Warszawa: 1882. p. 106.

14. Janiuk J. Gruźlica w okresie Młodej Polski i dwudziestolecia międzywojennego w teorii i praktyce medycznej. Med Nowożytna 2011;17(1):68.

15. Wielka Encyklopedia Powszechna Ilustrowana. T. XXIX. Warszawa: 1901. p. 270.

16. Lecznica Lwowskiego Towarzystwa Walki z Gruźlicą w Hołosku koło Lwowa. In: Polski Almanach Uzdrowisk. Kraków: Polskie Towarzystwo Balneologiczne; 1934. p. 400-1.

17. Encyklopedja Powszechna. T. XII. Warszawa: 1863. p. 71.

18. Selzer M. Wyniki lecznicze w uzdrowisku ludowym w Hołosku (Sprawozdanie drugie). Lw Tyg Lek 1911;6(11):157-9.

19. Selzer M. Próba urządzenia uzdrowiska ludowego dla piersiowo chorych w okolicy Lwowa (Hołosko Wielkie). Lw Tyg Lek 1912;7(32):566-77.

20. Selzer M. Próba urządzenia uzdrowiska ludowego dla piersiowo chorych w okolicy Lwowa (Hołosko Wielkie). Lw Tyg Lek 1912;7(33):577-9.

21. Selzer M. Uzdrowisko ludowe w Hołosku Wielkim w roku 1912 (Sprawozdanie IV). Lw Tyg Lek 1913;8(33):554-6.

22. Selzer M. Uzdrowisko ludowe w Hołosku Wielkim w roku 1912 (Sprawozdanie IV). Lw Tyg Lek 1913;8(34):567-9.

23. Woźniewski Z. Historyczny zarys leczenia gruźlicy płuc w Polsce. Warszawa: 1967. p. 55.

24. Bf: Rozmaitości. O barakach szpitalnych. Now Lek 1986;8(7):427.

25. Lewicki S, Praschil T, Orłowicz M. Przewodnik po zdrojowiskach i miejscowościach klimatycznych Galicyi obejmujący: zdrojowiska, uzdrowiska, zakłady lecznicze, latowiska, miejscowości klimatyczne oraz miejscowości posiadające źródła mineralne, wreszcie stacye turystyczne i sportów zimowych z mapą Galicyi. Lwów: 1912. p. 49.

26. Angielski S. Sprawozdanie lekarskie z Sanatorjum Towarzystwa do Walki z Gruźlicą w Hołosku Wielkiem za rok 1924. Polska Gazeta Lekarska 1925;4(13):308.

27. Kempa M., Lusek J. Tadeusz Ceypek (1904-1990). Portret z okruchów wspomnień. T. 3. Katowice: Biblioteka Historyczna Śląskiej Izby Lekarskiej; 2015. p. 22-3.

28. Tyszka K. O projekcie zwinięcia Sanatorjum przeciwgruźliczego we Lwowie. Pol Gaz Lek 1932;11(28):539-40.

29. Srebrny Z. Wspomnienie o tuberkulinie. Warszaw Czas Lek 1932;9(12-13): 275-8.

30. Zwolska Z. Robert Koch - bakteriolog, lekarz, humanista. Pamięci uczonego w 170. rocznicę Jego urodzin. Nauka 2013;10(4):166-7.

31. Supady J. Leczenie gruźlicy w Polsce na przełomie XIX i XX wieku. Pol Arch Med Wew 2007;117(9):433.

32. Koźniewski T. Działanie toksyczne tuberkuliny wprowadzanej przez drogi oddechowe. Rocz Lek 1908;2(3):358-9.

33. Gantz M. Obecny stan nauki o tuberkulinie. Now Lek 1904;16(1):1-37.

34. Godlewski M. Leczenie tuberkuliną w praktyce. Prz Lek 1909;48(5):83.

35. Sterling S. Stan obecny nauki o własnościach leczniczych tuberkuliny przy gruźlicy płuc. Czas Lek 1906;8(12):402.

36. Meissen: Die spezifische Diagnose und Therapie der Tuberkulose. Z Arztl Fortbild (Berl) 1910;10:37.

37. Selzer M. Sprawozdanie lekarskie o ruchu chorych i uwagi o leczeniu w sanatorium dla piersiowo chorych w Hołosku Wielkiem za czas od 1 X 20 do 31 XII 21 r. Lek Wojsk 1922;3(7):539. 